\title{
7 \\ Diversifying Narratives: Perceptions of a Weak Japan Facing a Rising China
}

Tine Walravens

\section{Introduction}

The idea of a dangerous China is omnipresent in the articulation of Japanese national identity, manifest in the daily media and public opinion, as well as among the policy elite. On 26 July 2013, the Japanese Ministry of Defense released an interim report on its defense posture, calling for an increase in the country's military capabilities and a more assertive role in regional security, reportedly due to the increased threats from an emboldened China and an unpredictable North Korea (DPRK). ${ }^{1}$ Indeed, the Kyodo News Agency headline read, 'Japan needs greater defensive power given threat from China, N. Korea'. ${ }^{2}$ A further article by the Yomiuri Shimbun on the eve of the publication of this interim report even omitted the DPRK threat, mentioning only China. ${ }^{3}$ Since 2011, Japanese White Papers on Defense have increasingly portrayed China's military build-up and its actions in the waters surrounding Japan as threats to national and regional security. This leaves the image of a weak Japan surpassed by and giving in to a growing China, especially on matters such as the economy and security. This constructed image supports the discursive establishment of the need for a tougher China policy, and accordingly provides a justification to adjust defense budgets.

However, this chapter aims to challenge the discourse of a weak Japan, demonstrating that in recent years, Japan has become an increasingly assertive player in Sino-Japanese relations. Furthermore, considering the indications from the interim report mentioned above about the direction in which Japanese foreign and security policy is heading, it will be argued that Japanese foreign policy is at a critical juncture. Its 
increasingly vocal stance in recent years is a manifestation of a changing national identity. The chapter draws on the paradigm set up by Lowell Dittmer and Samuel S. Kim in their search for a theory of national identity, focusing on China. ${ }^{4}$ They follow Sidney Verba, stating that national identity consists of all those who 'fall within the decision-making scope of the state'. ${ }^{5}$ National identity is thus considered to be the relationship between nation and state that is achieved when the people of that nation identify with the state. Dittmer and Kim further broaden the definition of the abstract term 'state' by specifying two dimensions: what the state does, and what the state is. Citing the Japanese term kokutai, a symbol system referring back to the founding experience of the nation, they define "what the state is as "national essence" '. What the state does consists of the actions taken by the state on behalf of the nation it represents. According to Dittmer and Kim, the state takes up several roles that accumulate to constitute an identity. Therefore, the state defines itself by what roles it plays as a collective unit, most visibly displayed in the international arena. A state's role is thus the total effect of state acts in relation to other states over a given period of time' ${ }^{6}$ In this chapter, I will focus primarily on this second dimension, the national roles, rather than on the symbol system within the process of identification. First, I will briefly elaborate on the national identity formation process in Japan and the dominant perspectives on Japan and China. I will then provide an alternative discourse through a case study and discursive examples.

\section{National identity formation in Japan}

The positioning of the 'Self' versus the 'Other' can be seen as a key element determining narrative structures in traditional histories of nations. ${ }^{7}$ Collective identities of a state are constructed in a complex and dynamic process by depicting the 'Self' as differing from a relevant reference, the 'Other'. ${ }^{8}$ David Campbell called the construction of identities through practices of 'othering' that generates differences the 'radical interdependence' of our political identities. ${ }^{9}$

Furthermore, national identity construction is not limited to one exclusive image of the 'Self' or the 'Other', but is characterized by a high level of inter-subjectivity through social interaction with multiple 'Others', resulting in various changing and even overlapping self-identities. ${ }^{10}$ Depending on the context and the particular 'Other' one is dealing with, a specific 'Self' will become manifest. ${ }^{11}$ There might be 'Others' with whom one wants to identify positively, while there are 'Others' from 


\section{China and her Periphery}

whom one likes to differentiate oneself and whose antagonism helps to dramatize the importance of defending the values of 'us' against 'them'. This implies that the definition of the 'Other' is highly dependent on the identity of the 'Self' and not a priori known. Identity is, in this chapter, seen as embedded in social relations and as contextual, layered, relational, and susceptible to change. The given context in this chapter is the negotiation between two social groups, which is often power-laden when concerning two nation-states or entire populations.

In the case of Japan, China has been a very significant 'Other' in the historical process of state identity formation. The first nascent Japanese cultural and national consciousness in the 18th century emphasized precisely 'that which made the Japanese irreducibly Japanese, meaning the same, and thereby different from the (Chinese) Other' ${ }^{12}$ The emergence of 'national studies' (kokugaku) ${ }^{13}$ during the 18th and 19th centuries aimed precisely at challenging Chinese Neo-Confucianism and demonstrating the superiority of Japanese over Chinese culture, by placing a 'civilized' Japan against an 'uncivilized China'. ${ }^{14}$ At this early stage of Japanese national identity formation, the nation's cultural consciousness was clearly formed in juxtaposition with China, precisely as China was for Japan the significant reference point in time. It is fair to state that the modern Japanese 'Self' was born from the encounter with the 'othered' Chinese. It is precisely through these processes of 'othering' that 'Japan' becomes what it is in relation to China. Nevertheless, 'the Japanese' or 'the Chinese' are not fixed categories but rather dynamic processes that change over time, space and social context.

\section{Perceptions of a rising China}

As Northeast Asia is changing, China's reawakening and seemingly assertive pursuit of regional interests has unsettled neighboring states, and not least Japan. China's re-emergence is a fact and its enhanced capabilities, influence, and related synergies are beyond the scope of this chapter. ${ }^{15}$ This rise has occurred parallel with an increasing nationalism, often seen as a reaction against the century of humiliation. Intense debates as to how the world and, in particular, East Asian countries react and position themselves vis-à-vis a rising China are ample, such as the numerous analyses of the US pivot to Asia, or the international reactions to the South China Sea and East China Sea territorial disputes. The effects on regional security raise concerns in East Asia and beyond. On the one hand, Western scholars focus on China's governance problems and the state's effectiveness in dealing with social 
problems. On the other hand, China's role in the international system and China's military capabilities and intentions in the region are analyzed, and increasingly non-military factors of security are also assessed.

Not only in East Asia, but also in the West, portrayals of China have become primarily images of a blunt, aggressive and assertive powerhouse, rattling the region. The country is often perceived as 'the Other', as 'the problem' or 'the cheater', 'unfair' and not playing by the rules. ${ }^{16}$ Indeed, China's record in terms of the environment, human rights, intellectual property, energy security, climate change, food safety, cyber terrorism, and so forth are widely perceived in a negative way. Neighboring countries worry about China's military build-up, its lack of transparency about defense expenditures, and its vague long-term ambitions in the region. ${ }^{17}$

An outcome of this perceived challenge for regional stability, which regards growing power and capability as a threat, is the so-called 'China Threat' thesis mentioned above. ${ }^{18}$ Growing uneasiness about the implications of China's rise is reflected in the current discourse, often characterized by Sinophobia, the China Threat thesis and an image of an increasingly assertive China. ${ }^{19}$ It is not merely a debate about the possible implications of China becoming an emerging power for international peace and security. Instead it involves strongly held, yet sharply differing, political perspectives within a policy community that result in feelings of admiration, fear, or loathing of the Chinese regime. ${ }^{20}$ The categorization of the other as a threat automatically puts the self in comparison with a menacing other and can imply a certain weakness or fear. In accordance with the favored interpretation of China's rise, conclusions are then voiced concerning the challenges, predictions about the future, and recommendations for policy formation. ${ }^{21}$

The post-2008 incidents of so-called provocative Chinese behavior on the international scene, such as the behavior of Chinese officials at the UN Copenhagen Climate Change Summit in 2009 or its assertive policy towards its neighbors on territorial disputes, certainly accelerated reactions to the rise of China. ${ }^{22}$ Those reactions are not necessarily caused by the provocations, but rather by perceptions of power. However, it is important to realize that differing assessments of the consequences of China's rapid economic development have been made. Elizabeth Wishnick breaks down the debate among Western scholars about China's rise into three positions: (1) China as a potential threat, (2) China remaining weak and posing no threat, and (3) China becoming increasingly responsible and integrated..$^{23}$ 
China becoming more powerful militarily

"Negative," Increases since 2005

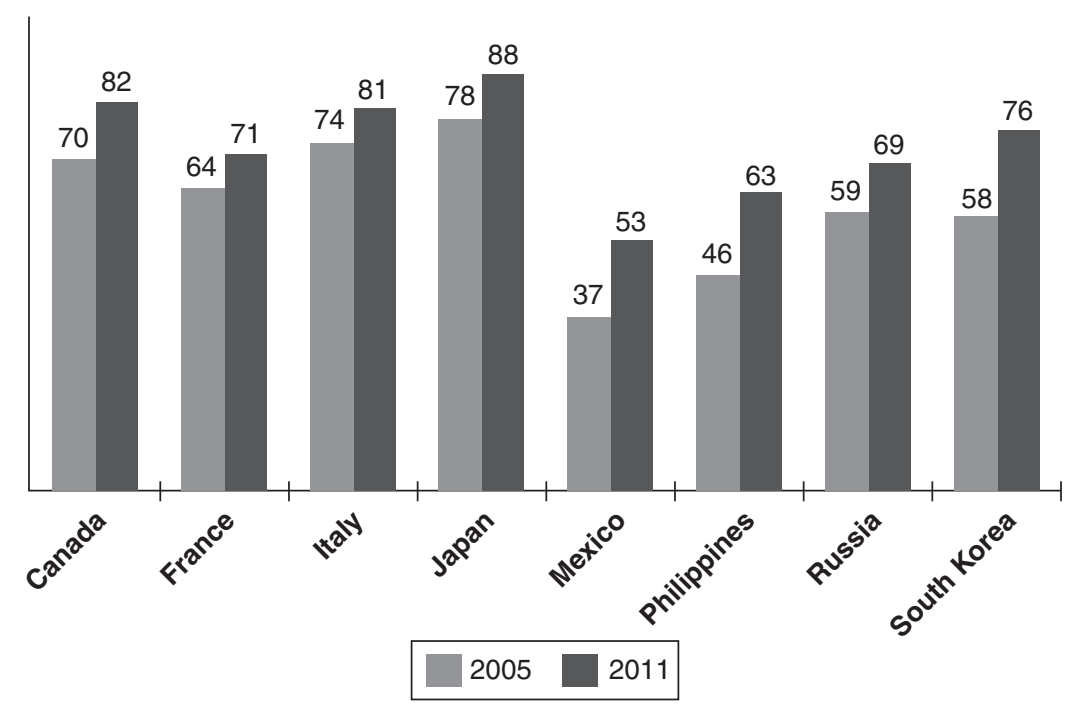

Asked of half of sample in 2011

Figure 7.1 Rising concern about China's increasing power: Global Poll 2011(1) Source: BBC World Service, GlobeScan/PIPA, 'Rising Concern about China's Increasing Power: Global Poll', 27 March 2011, p.4. Available at http://www.globescan.com/images/images/ pressreleases/bbc2011_china/bbc2011_china.pdf.

Nevertheless, surveys show that the rapid rise in China's overall economic capacity and military strength has provoked increasing anxiety worldwide. A multinational opinion survey concerning global views on China by GlobeScan for the BBC usefully compared responses from 2005 and 2011, and shows a rapid attitudinal shift: in just six years' time negative views of China's economic and military role in the world increased not only regionally but also globally. ${ }^{24}$ (See Figure 7.1 and Figure 7.2)

\section{Perceptions of a weak Japan}

A fundamental feature of East Asia's political economy since the 1990s is a rising China and a rather stagnating Japan. This marks a new era for Tokyo's relations with Beijing, as Japan was accustomed to the phenomenon of a 'strong Japan and stagnant China' that was the case for more than a century. A re-emerging powerful China thus provides a new yardstick against which Japan measures itself. 


\section{China becoming more powerful economically/militarily}

"Positive" vs "Negative," Average of 18 Tracking countries* $2005-2011$

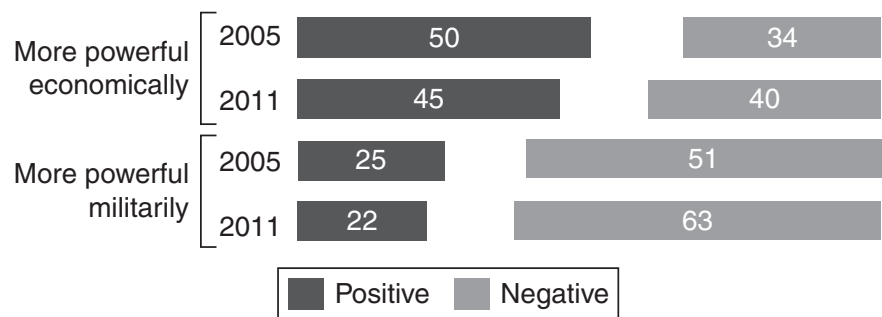

The white space in this chart represents "Neither positive or negative," and "DK/NA."

Asked of half of sample

*Tracking countries include Australia, Brazil, Canada, France, Germany, India, Indonesia, Italy, Japan, Mexico, the Philippines, Russia, South Africa, South Korea, Spain, Turkey, the United Kingdom, and the USA.

AQ1 Figure 7.2 Rising concern about China's increasing power: Global Poll 2011(2) Source: BBC World Service, GlobeScan/PIPA, 'Rising Concern about China's Increasing Power: Global Poll', 27 March 2011, p.3. Available at http://www.globescan.com/images/images/ pressreleases/bbc2011_china/bbc2011_china.pdf.

Since diplomatic normalization in the 1970s, Sino-Japanese relations have been characterized by steadily increasing economic and socio-cultural interactions. Yet this growing interdependence developed concurrently with ever more frequent bilateral tensions over history, national identity, and territorial integrity. ${ }^{25}$ Public opinion on both sides shows growing mutual antagonism. ${ }^{26}$

Sino-Japanese relations, being at the core of East Asian regional stability, are not in the least 'affected' by the so-called power shift in Asia, as they are increasingly characterized by friction and competition. Contrary to the widespread understanding that Japan is trying to balance or constrain the rise of China in terms of its military budget or enhanced cooperation with the US, I follow Bjorn Jerdén and Linus Hagström in seeing Japan as having been relatively supportive and deferential to the rise of China. ${ }^{27}$ Despite many hostile interactions between the two countries, several factors demonstrate Japan's accommodation of the rise of China - most visibly in terms of economic development and non-interference on domestic affairs, such as the Tiananmen incident or Tibet. I will argue that despite this accommodating stance, which persisted up until 2010, Japanese foreign policy towards China is showing a 


\section{PROOF}

change in comportment in recent years and thus may be at a historical crossroads.

Notwithstanding these supporting dynamics, a recurrent set of issues regarding history, nationalism, and identity, particularly after the mid1990s, have produced ups and downs in the diplomatic relationship and persistent growth in negative public opinion. The narrative, voiced by elite policymakers and in public opinion, clearly represented China as a threat. However, this narrative was absent, or at least less apparent, in the concrete output of the Japanese political system and the China policy of the Japanese government.

Moreover, the latter image of Sino-Japanese relations, portraying Japan as an accommodator to the rise of China, was not reproduced at grassroots level. Even during and after the reign of Prime Minister Fukuda Yasuo (LDP, 2006-2007), who followed Prime Minister Koizumi Junichirō (LDP, 2001-2006) and who was quite successful in improving bilateral ties, public opinion did not reflect this political development (See Figure 7.3).

The so-called 'declinist narrative' covers in a general fashion the many problems Japan is dealing with nowadays. In the most obvious way, the rise of China coincides with a stagnating Japanese economy. But there is more to the 'Japan is weak' narrative than this so-called lost decade, or even lost decades. ${ }^{28}$ The country suffers from political instability (Shinzō

図10 中国に詨する親近感

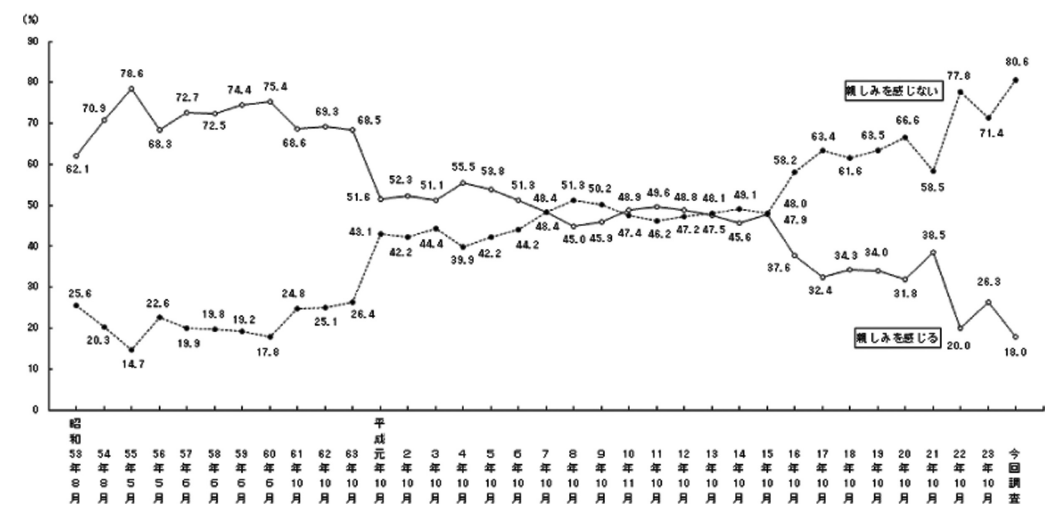

Figure 7.3 Affinity towards China

Source: Prime Minister's Cabinet Office, Secretariat, Public Relations Office, Government of Japan (内閣府大臣官房政府広報室, Naikakufu Daijin Kanbô Seifu Kôhôshitu), 'Public Opinion Survey on Diplomacy' (外交に関する世論調査, Gaikô ni kan suru seiron chôsa), October 2012, Chart 10. Available at http://www8.cao.go.jp/survey/h24/h24-gaiko/index.html. 
Abe being the sixth prime minister since 2007) and a loss of confidence in the government's ability to respond to crises and territorial and diplomatic disputes with neighboring countries, and the lost illusion of once having been the leading nation in Asia. ${ }^{29}$ The Japanese public is critical of its government's inability to manage relations with China, while at the same time suspicious of China itself. Shortcomings in the corporate sector are evident in a series of corruption scandals and product safety fiascos. Furthermore, the country is suffering from several negative social phenomena including falling birth rates, growing unemployment, an income gap, increasing crime rates, and rising suicide figures. ${ }^{30}$

The 'Japan is weak' discourse can be seen as a spinoff of this 'declinist narrative', focusing mainly on Japan's actions in its foreign and security policy. The clear power shift in Asia manifests itself through diplomatic rows in which Japan is often perceived to acquiesce to an increasingly aggressive and assertive China. ${ }^{31}$

This chapter outlines an alternative discourse to the dominant narrative of Sino-Japanese rivalry, that of a weak Japan versus an aggressive China. I argue that the concept of national identity matters, reflecting the centrality of 'China' (or the constructed image thereof) in Japanese national identity formation. It is not my aim to endorse a single international relations theory or analytical framework regarding possible responses to an emerging power in the region, or to predict any potential future scenario for Sino-Japanese relations. I would rather like to provide a different narrative, challenging the dominant way in which Japanese and foreign media, policymaking, and academic discourses perceive and analyze tensions between China and Japan as a logical consequence or compelling evidence of the power shift: a rising China characterized by increasing assertiveness and a declining Japan proven by its diplomatic defeat.

\section{A weak Japan? - Diversifying the dominant narrative ${ }^{32}$}

First, the more general 'declinist narrative' has already been challenged and contested, citing as evidence Japan's continued high living standards, its trade performance and its geopolitical importance in the region. ${ }^{33}$ For example, Tanaka Hitoshi, former Japanese deputy minister of foreign affairs, states the following:

The myth that Japan is in decline and no longer important in the era of a rising China is a dangerous misperception. While Japan's economy faces stiff challenges, it is still fundamentally strong and 


\section{PROOF}

will bounce back. Moreover, the rise of China has increased, rather than diminished, Japan's geopolitical importance. ${ }^{34}$

Nevertheless, the China Threat paranoia and the declinist theory loom large in the minds of Japanese and foreign policymakers, commentators and media. The image of Japan as weak and subservient in its foreign and security policy provides a framework, enabling certain interpretations and disabling others. Policymakers voice negative opinions on China in terms of politics, the economy, or the military and thus succeed in steering public opinion towards (or rather against) China, often exploited for domestic political gains. A weak Japan narrative makes tougher action against China seem inevitable.

National identity is constructed vis-à-vis other identities, which in turn creates expectations about those nations' comportment. By dispersing this 'Japan is weak' narrative, and the more general declinist discourse, right-wing extremists and nationalists in Japan strive for a stronger stance against China, the 'negative' Other, with whom one does not wish to identify. ${ }^{35}$ This, in turn, deepens the suspicion in China about the impact of rightist thoughts and nationalist opinions in Japan. The situation of international enmity or threat seems particularly well suited to the intensification of national identification, 'us' versus 'them'.

Dankwart Rustow wrote in 1993 that 'the talk about the nation has been loudest where the sense of nationality has remained weakest', and he cited Japan as a counter-example. ${ }^{36}$ Remarkably, in its current situation Japan could be listed as an example of a country where the nation as a topic is omnipresent, indicating a weak sense of nationality according to Rustow. We might in turn conclude that this suggests identity problems, a sense of national identity being threatened or unstable, or even an identity crisis.

In the following section I will focus on one case study and additional examples of changes in Japanese behavior to underpin the argument that, in contrast with the weak image presented, Japan recently has become a more proactive, even assertive power on issues such as territory and history, while at the same time maintaining its alleged weak image for strategic purposes. It is, I will argue, Japan itself that has begun to take a more aggressive stance and more provocative actions towards China in recent years.

\subsection{The 2010 Senkaku boat collision incident}

In September 2010, a Japanese coastguard patrol boat discovered a Chinese fishing trawler operating close to the Senkaku Islands 
(Senkaku-shotō, or Diaoyudao in Chinese). As it was outside the area agreed for Chinese fishing and within Japanese-controlled waters, the Chinese boat was ordered to stop for inspection. The captain, Zhan Qixiong, refused - supposedly - tried to flee and collided with the Japanese vessel. ${ }^{37}$ The Japanese coastguard boarded the Chinese vessel and arrested the captain and its 14 crew members for 'obstructing the duties of public officials' and for 'illegal fishing'. Moreover, the Japanese government stated that they would handle the incident according to domestic law, as they saw the Senkaku Islands as Japanese territory. ${ }^{38}$

In response to the detention, the Chinese government reacted with diplomatic protests, asking for the release of the captain and his crew. On six occasions (once after midnight) Beijing summoned the Japanese ambassador to China, Niwa Uichirō, to repeat its demand and in so doing also restating the Chinese historical claim to the islands. The crew was released on 13 September, while on 19 September the captain's detention was extended by another ten days. Five days before the end of this term, however, on 24 September, Japan released Zhan, stating that keeping the captain in custody would not be appropriate and that it was having a considerable impact on Sino-Japan relations. ${ }^{39}$

In the aftermath of the collision, public protest erupted in both countries. Following the detention of the captain and his crew, the Chinese government also reacted by suspending diplomatic talks (including discussions about joint gas development in the East China Sea), cancelling non-governmental exchanges (for example, Japanese students invited to the Expo in Shanghai), and discouraging Chinese tourism to Japan.

The arrest and detention of the Chinese captain were arguably unprecedented measures taken by the Japanese government, which could explain the large number of public protests that erupted in China. ${ }^{40}$ These public protests and the suspended diplomatic exchanges can without doubt be analyzed as immediate Chinese reactions to Japan's fierce handling of the trawler collision. Yet other actions with no proven connection to the Senkaku Islands spat but taken shortly after the event were all too easily perceived and analyzed as having a causal relationship with the bilateral dispute by international media and policy analysts, who readily pronounced a Chinese victory over a diplomatically weak-kneed Japan. ${ }^{41}$

In the aftermath of the trawler incident, four Japanese employees of Fujita Corporation were arrested for entering a military zone around Shijiazhuang (Hebei Province) in China and filming military targets. Despite the fact that the Japanese did indeed enter a restricted military zone without permission and did film there, analysts around the 


\section{PROOF}

world immediately interpreted the arrest as Chinese retaliation. The same was true in the case a two-month halt in the Chinese export of rare earth metals to Japan starting at the end of September, which was also perceived as Chinese pressure to release Zhan Qixiong. Although the timing of the halt could easily imply otherwise, Beijing did not officially acknowledge the embargo or connect it to the bilateral dispute. In fact, China had already announced a crackdown on export quota in August 2010, and there is evidence that even before the island dispute erupted again on 7 September, there had already been talks about Chinese upcoming restrictions on rare earth exports (consistent with WTO rules) during the Japan-China High-Level Economic Dialogue in August that same year. ${ }^{42}$

There is no clear evidence in either case to support the retaliation narrative, but it is also impossible to prove that they were not connected to the Senkaku Islands 'spat'. However, actions by both governments are seen almost automatically within the pre-existing framework of a rising and hence more aggressive China versus a weak and defeated Japan. Despite the aforementioned arguments, the discourse generally depicted Tokyo as the reasonable party, while China was seen as the aggressor. ${ }^{43}$ Nevertheless, Japan took unprecedented fierce measures in capturing and detaining the captain, which could be perceived as increasingly assertive behavior by the Japanese. The incident undoubtedly revived the issue of national identity in both countries.

\subsection{Pragmatic use of the discourse and provocative behavior in Japan}

Within the context of Sino-Japanese relations, the 'Japan is weak' $^{\prime}$ discourse is easily utilized in a strategic way by policymakers. The underlying thought is that power is in large part realized through the manifestation of ideas that are already present in the people's minds. Policymakers voice their negative opinions of China, its politics or economy, and as such succeed in steering public opinion against China. On the domestic level, nationalists arouse public opinion and rally public support for a tougher stance against China. Depicting Japan as weak and China as strong and aggressive makes certain changes in foreign security policy seem inevitable. The efforts of Ishihara Shintarō, then governor of Tokyo, to try to purchase three of the Senkaku Islands could in this light be seen as a set-up to trigger the above-mentioned vicious circle. ${ }^{44}$ Although the government nationalized the islands in order to prevent matters getting worse, it was perceived very differently by Chinese public opinion. The action was seen as a strong provocation 
at all levels of Chinese society and led to yet another series of diplomatic back-and-forth fighting and the eruption of anti-Japanese public protests and violence against Japanese residents, students and tourists in China. Japanese and Chinese nationalism inflame each other. This vicious circle effect of enhanced mutual antagonism is often triggered by provocations by Japanese right-wing nationalists. In turn, it creates the impression among the Japanese public that tougher action against China is required, which legitimizes changes in Japan's foreign policy.

By using the same image of an aggressive and irrational China, Japan is fishing for US reassurances about the coverage of the US-Japan alliance on the islands. ${ }^{45}$ The increased US attention to Asia is welcomed by Japan. Japan's concerns about China make the US a necessary partner in the region. Furthermore, any incident with China is eagerly used to distract the public from the earlier discussed domestic problems and unite them against the 'other' China.

As mentioned above, a situation of international enmity is very useful to intensify national identification, and as such Japanese policymakers, nationalists, and media continuously feed the China Threat thesis to the public. Japan's Defense White Papers since 2011 cite China as a matter of concern for the nation and for the region. ${ }^{46}$ In particular the latest Defense White Paper of 2013, the first one since the re-election of Prime Minister Abe, is remarkable for its rather vigilant tone about the regional security challenges and Japan's planned response. ${ }^{47}$ The foreword mentions the DPRK's recent satellite and nuclear tests and the 'rapid expansion and intensification of activities by China in the waters and airspace around Japan, including intrusion into Japanese territorial waters and airspace' as the most important challenges to Japanese national security. ${ }^{48}$ Within hours of the publication of the document, China reacted fiercely against these reportedly unfounded accusations by Japan. ${ }^{49}$

Domestic political abuse and misuse of nationalist sentiment have created a vicious circle, in both countries, that fuels mutually antagonistic perceptions. However, I agree with Chung-in Moon and Seung-Won Suh that Japan is 'the origin of the chain reaction', displaying a more aggressive and assertive stance in recent years. They even state that Japanese (mostly right-wing) politicians intentionally provoke public discontent over historical issues in order to rally domestic support, thereby enabling Chinese nationalists to exploit this to mobilize the Chinese public and strengthen their own legitimacy. ${ }^{50}$ The salient antiJapanese stance among the Chinese public in turn agitates the Japanese people and heavily influences public opinion. The Japanese nationalists 


\section{China and her Periphery}

legitimize their own harsh rhetoric against China by emphasizing the strong anti-Japanese sentiment in China. Akaha Tsuneo usefully showed that the stronger the Chinese criticism of Japan, the more determined nationalists are in their rejection of these criticisms, and as such they appeal to the general public. Via the selective use of events and ideas such as the idealization of the Japanese past versus its allegedly weak international position now, the nationalists frame their discourse with a prominent, negative role for China. ${ }^{51}$

Further adding to the image of an increasingly assertive Japan is the policy speech Abe intended to give in Jakarta in January 2013, shortly after his re-election in December 2012. The speech, entitled 'The Bounty of the Open Seas: Five New Principles for Japanese Diplomacy', was never given due to itinerary changes, but the text was widely distributed through diplomatic channels overseas. ${ }^{52}$ The speech was generally regarded as an open invitation from Japan to Southeast Asia for further cooperation, connecting the nations of 'Maritime Asia', read between the lines as 'against China'. The speech also mentions: 'ensuring that the seas, which are the most vital commons to us all, are governed by laws and rules, not by might.' As this speech was written during ongoing bilateral rows about the Senkaku Islands, the link with China is easily made. Abe reiterated Japan's position on the islands issue unambiguously in February 2013 in his 'Japan is back' speech, stating: 'We simply cannot tolerate any challenge now, and in the future. No nation should make any miscalculation about the firmness of our resolve. ${ }^{53}$

Equally fierce statements about the sovereignty of the Senkaku Islands have also been dispersed through his diplomatic apparatus. On the occasion of Abe's visit to the US in early 2013 his foreign minister, Kishida Fumio, conveyed a similar message to the outside world, generally perceived as valuing China as a strategic partner but not giving in on territorial issues:

[...]with regards to China, the Japan-Sino relationship is one of the most important bilateral relationships for our nation. [...]Further, while Japan will not concede and will uphold our fundamental position that the Senkaku Islands are an inherent territory of Japan, we intend to respond calmly so as not to provoke China. ${ }^{54}$

A speech by Katayama Kazuyuki, Deputy Chief of Mission at the Embassy of Japan in Brussels in December 2012, stated it as follows: 
Il ne peut y avoir donc aucune polémique sur la question de l'appartenance territoriale des îles Senkaku, le Japon exerçant effectivement son autorité sur ce territoire. (There can be no debate on the issue of territorial ownership of Senkaku Islands, Japan actually exercising its authority over this territory). ${ }^{55}$

Most recently, several days before the parliamentary elections of 21 July 2013, Abe again fiercely restated Japan's claims to the Senkaku Islands during a visit to the nearby Ishigaki and Miyako islands, appealing to nationalism when addressing his coastguard officers and stationed soldiers. ${ }^{56}$

It is remarkable to note that this more assertive rhetoric still appears in parallel with the 'Japan is weak' narrative, as is demonstrated in the same 'Bounty of the Open Seas' speech, in which Abe states: 'If the Japanese need one thing now, that thing is confidence. [...]Japan once had tremendous confidence, but there is a shortage of it today. ${ }^{57}$ Parallel to an increasingly proactive stance against Beijing, the 'Japan is weak' discourse is strategically maintained and utilized by policymakers within the context of Sino-Japanese relations. Overall, these signs of an increasingly assertive rhetoric, particularly on territorial integrity, are fairly recent developments, having arisen around $2010 .^{58}$

What does this change in diplomatic behavior and policy imply about Japan's national identity? Referring again to Dittmer and Kim, the evolution of a national identity is the result of three factors: first, the aspirations projected by the 'nation'; second, the domestic political situation; and third, foreign policy experiences. The last factor is the re-emergence of China and its more active pursuit of its interests in the region, which leaves clear traces among the Japanese public, politicians, and media. Furthermore, the deplorable state of Japanese domestic politics and the aftermath of the triple disaster of March 2011 make for an unstable domestic political situation which is arguably shown by the ruling party switch (LDP-DPJ-LDP) between 2009 and 2013. The nation's aspirations, mirrored by public opinion, show a decline in friendly feelings towards China in recent years (see Figure 7.3), and that has arguably led to expectations for a tougher stance against China by the state.

As mentioned above, a national role is what the state does as a collective unit, most visibly on the international scene. National roles are thus used to mobilize, test, or confirm an identity through interactions with other players in the international arena, in this case China. A certain faction of the Japanese political elite selectively intensifies and moderates nationalism in order to rally domestic support for a tough Japanese 


\section{China and her Periphery}

role versus China. This phenomenon is most visible in the actions of Abe (LDP), the former governor of Tokyo Ishihara Shintarō, and the mayor of Osaka Tōru Hashimoto, the latter two both from the nationalist Japan Restoration Party. Underlying a change in the nation's role, there is mostly a relatively stable purpose, which in turn creates identity. What might otherwise seem random alterations to diplomatic behavior are in fact manifestations of a conscious direction of roles in order to meet domestic expectations or party positions. The overall aim of the Japanese nationalists is to eliminate what they consider 'a defeatist view of Japan' and to restore their dignity. ${ }^{59}$

Further following Dittmer and Kim, there is a stratified hierarchy of self-defining political actions, containing at least five different levels ranging from visible and flexible to invisible and invariant: public opinion, policies, principles, policy platform, and at the basis national identity. National identity at the basis should be seen as the most stable and basic element in this hierarchy. As long as this basis is stable, it will be reflected in congruence at all levels. Yet a sharp incongruity at these levels may be expected to trigger an identity crisis. ${ }^{60}$ As mentioned earlier, until recently, the Japanese official policy of accommodating the rise of China was not compatible with public opinion, which was strongly directed against China. From normalization in 1978 until approximately 2010 Japan actually supported China's growth in many ways. Notwithstanding recurring bilateral rows on issues of history and territory often triggered by the Japanese side, they did not affect China's long-term 'core interests' overall until around $2010 .{ }^{61}$ Remarkably, despite the aforementioned efforts by the Japanese government to reinforce the bilateral relationship, those efforts have not resonated with the wider segments of the Japanese public. At the same time, the negative public perception of China and loud calls from political extremists have not directly led to concrete policy action towards China. Considering this incongruity between public opinion and policymaking, it can be concluded that this incompatibility could have precipitated an identity crisis. As Lucien Pye points out: 'In the process of political development, an identity crisis occurs when a community finds that what it had once unquestionably accepted as the physical and psychological definitions of its collective self are no longer acceptable under new historic conditions' ${ }^{62}$ The changing historical context in which Japanese national identity is constructed is now affecting the discourse of the 'Self' that Japan sees in the region. The changes that occurred in Japan's China policy in 2010 may be an appropriate redefinition or adjustment of its national identity as a perceived solution to this identity crisis. 


\section{Conclusion}

National identity is formed by depicting the 'Self' against the 'Other' within a certain historical framework. The centrality of 'the China problem' in the articulation of Japanese national identity is widely reflected in the realms of public opinion, domestic policymaking, and international politics and demonstrates the importance of labeling and categorizing in identity construction.

In the context of a rising China, the broadly dispersed narrative of a weak Japan versus an assertive China is diversified by the image of a gradually more vocal and assertive Japan. This alteration in behavior can be analyzed as the result of an identity crisis, caused by diverging ideas on various levels of Japanese identity. How Japan sees itself within this new context, and facing China, needs to be redefined and adjusted.

The constructed idea of a weak Japan - disregarding the fact and fiction about it - can easily be placed within this framework. It is strategically (re)created, promoted, and utilized by policymakers to legitimize their own rule and a tougher stance against China - uniting the nation against China to divert the focus from domestic problems. This narrative is echoed in public opinion and now finds its way to the official level, as seen in the increasingly strong rhetoric against China by diplomats and policymakers compared to their previously relatively accommodating stance. The changing regional context seems to have triggered a change in the structure of Japanese domestic politics and a re-evaluation of national identity in the formation of this foreign policy. This fierce Japanese voice could be a harbinger of the manifestation of a new selfidentity through foreign policy, a self-image much more reflective of the strongly anti-Chinese public opinion than was the case in the previous three decades.

\section{Notes}

1. Ministry of Defense, Government of Japan, 'Interim report concerning the defense posture review' (Bōeiryoku no arikata kentō ni kansuru chūkan), 26 July 2013. http://www.mod.go.jp/j/approach/agenda/2013_ chukan/20130726.pdf (accessed 28 July 2013).

2. 'Japan needs greater defensive power given threat from China, N. Korea', Kyodo News Agency, 2 July 2013. http://english.kyodonews.jp/news/2013/07/ 237740.html (accessed 28 July 2013).

3. 'The National Defense Guidelines: Study on drones and cyber-enabled enforcement' (Mujin teisatsuki kentōo, saibā taiō kyōka ... bōei taikō), Yomiuri Shimbun, 25 July 2013. http://www.yomiuri.co.jp/politics/news/20130724OYT1T01392.htm?from-ylist (accessed 28 July 2013). 
4. L. Dittmer and S. S. Kim (1993) 'In search of a theory of national identity', in L. Dittmer and S. S. Kim (eds.) China's Quest for National Identity (Ithaca and London: Cornell University Press), pp.1-31 based their theory on E. Erikson (1956) on individual identity and the theories of S. Verba and L. Pye (1971) on national identity, while adding a synthetic dimension to the merely analytic explanation of the term.

5. S. Verba (1971) 'Sequences and development', in L. Binder and J. La Palombara (eds.) Crises and Sequences in Political Development (Princeton: Princeton University Press), pp.283-316.

6. Dittmer and Kim, 'In search of a theory of national identity', p.15.

7. See P. Duara (2008) 'Historical narratives and trans-nationalism in East Asia', in S. Richter (ed.) Contested Views of a Common Past. Revisions of History in Contemporary East Asia (Frankfurt am Main and New York: Campus), p.105.

8. The Self-Other approach was developed within social theory, but is also increasingly used in IR theory. See Th. Diez (2004) 'Europe's others and the return of geopolitics', Cambridge Review of International Affairs, 17/2, 321; I. B. Neumann (1996) 'Self and other in international relations', European Journal of International Relations, 2/2, 139-74.

9. See D. Campbell (1993) Politics without Principle: Sovereignty, Ethics and the Narratives of the Gulf War (Boulder: Lynne Rienner), p.95.

10. See Sh. Suzuki (2007) 'The importance of "Othering" in China's national identity: Sino-Japanese relations as a stage of identity conflicts', The Pacific Review, 20/2, 24-5.

11. Japan's articulation of the nation's self-identity is thus not reducible solely to the rise of China and the changing international environment. Depicting China as the 'Other' is only one factor among other international influences, domestic political developments and global actors that play a role in this highly complex social process. The Yoshida Doctrine and the 1995 political system, among others, also had a profound impact on Japanese national identity. See the contribution by Kristof Elsen in this volume.

12. H. Befu (ed.) (1993) Cultural Nationalism in East Asia, Representation and Identity (Berkeley: University of California Press), pp.82-4; taken from H. D. Harootunion (1988) Things Seen and Unseen: Discourse and Ideology in Tokugawa Nativism (Chicago: University of Chicago Press), p.409.

13. See H. Naga and S. Matsumoto (eds.) (1971) Nihon shisō taikei, vol. 51: Kokugaku undo no shisō (Tokyo: Iwanami Shoten).

14. E. Ohnuki-Tierney (1993) Rice as Self. Japanese Identities through Time (Princeton: Princeton University Press), pp.102-4.

15. A rising power is here defined as a state in the process of agglomerating capability at a rate that exceeds that of other powers. In China's case, 'rise' reflects the country's transformation from a regional middle-ranking power to a great power/superpower in the international system. Not only have Chinese capabilities grown in absolute terms, but inherent in the understanding of China's rise is also the notion that it has occurred at least partly at the expense of other states' relative power. X. Yan (2006) World Politics: Views from China: International Security (Beijing: New World Press), pp.12-13.

16. 'Rising concern about China's increasing power: Global poll', BBC World Service, GlobeScan/PIPA, 27 March 2011, pp.4, 14. http://www.globescan.com/ 
images/pressreleases/bbc2011_china/bbc2011_china.pdf (accessed 28 July 2013).

17. K. Srinivasan (2013) 'China's rise: Perceptions and misperceptions', ECIPE Policy Briefs 6. http://www.ecipe.org/media/publication_pdfs/PB6.pdf (accessed 28 July 2013). M. Swaine (2010) 'Perceptions of an assertive China', China Leadership Monitor 32, 1-19. http://www.lepointinternational.com/ attachments/531_Perceptions\%20of\%20an\%20Assertive\%20China.pdf (accessed 28 July 2013).

18. Ch. Moon and S. Suh (2008) 'Identity politics, nationalism, and the future of the Northeast Asian order', in J. Ikenberry and Ch. Moon (eds.) The U.S. and Northeast Asia (Landham: Rowman \& Littlefield), pp.198-203. Also, according to L. Hagström, the notion of the 'China Threat' is mostly coming from US researchers and policymakers, and is related to the strategic interests of the US in the region, and can therefore provide them with a compelling argument for justifying their presence in the East Asian region. 'Interview with Linus Hagström', Japan Foreign Policy Observatory, 21 June 2012. http://www. japanfpo.org/2012/06/interview-with-linus-hogstrom.html (accessed 28 July 2013).

19. See Moon and Suh, 'Identity politics, nationalism, and the future of the Northeast Asian order', p.209; N. Bisley (2011) 'Biding and hiding no longer: A more assertive China rattles the region', Global Asia, 6/4, 62-73; J. H. Chung (2009) 'East Asia responds to the rise of China: Patterns and variations', Pacific Affairs, 82/4, 663.

20. For a proposal of three different logics to substantiate the 'China Threat' thesis: M. Xia (2007) 'China rises companion: "China Threat" or a "peaceful rise of China"?', The New York Times. http://www.nytimes.com/ref/college/ coll-china-politics-007.html (accessed 28 July 2013).

21. M. C. Williams (1998) 'Modernity, identity and security: A comment on the "Copenhagen controversy" ', Review of International Studies, 24/3, 435.

22. For more on this, see Swaine, 'Perceptions of an assertive China', 1-19. For a reaction to this so-called 'new' assertiveness, see A. I. Johnston (2013) 'How new and assertive is China's new assertiveness?', International Security, 37/4, $7-48$.

23. E. Wishnick (2005) 'China as a risk society', Working paper, Politics, Governance, and Security Series, 12, 1-7.

24. It is interesting to see that this negatively perceived image goes beyond East Asia as Germany has the highest percentage of respondents, equal with Japan, 88 per cent, feeling concerned about China becoming more powerful militarily. See 'Rising concern about China's increasing power: Global poll', pp.4, 14 .

25. Some examples of these bilateral controversies include the territorial dispute about the Senkaku/Diaoyutai Islands, Japanese alleged historical revisionism about the war past and the closely related history textbook controversy, and official visits by the Japanese political elite to the Yasukuni Shrine.

26. 'The 9th Japan-China Public Opinion Poll. Analysis Report of the comparative data', The Genron NPO and China Daily (12 August 2013), p.4. http://www.genron-npo.net/english/index.php?option=com_content\& view=article\&id=59:the-9th-japan-china-public-opinion-poll\&catid=é: research\&Itemid=4 (accessed 12 August 2013). 
27. B. Jerdén and L. Hagström (2012) 'Rethinking Japan's China policy: Japan as an accommodator in the rise of China, 1978-2011', Journal of East Asian Studies, 12, 215-50 cite, among others, the Japanese Overseas Development Assistance policy to China and non-interference on matters such as Tibet or Tiananmen as arguments.

28. See the contribution by Kristof Elsen in this volume.

29. 'Japan's lost decade', The Economist, 26 September 2002. H. Tanaka, 'China's spat with Japan: Out but not over', The Economist, 24 September 2010. The so-called 'lost decades of Japan' narrative is being contested and challenged by several well-known economists and Japan experts such as W. Cline (The International Economy), P. Krugman (Princeton University), and E. Fingleton (Forbes).

30. H. Satō (2010) 'Japan: What future with China?', in L. P. Er, N. Ganesan and C. Dürkop (eds.) East Asia's Relations with a Rising China (Sankt Augustin: Konrad Adenauer Stifting), p.183.

31. H. Tanaka (2010) 'The Senkaku Islands and mending Japan-China relations', East Asia Insights 5/5. http://www.jcie.or.jp/insights/5-5.html; H. Tanaka, former Japanese deputy minister of foreign affairs, clearly shows that these are two different naratives. He overtly criticizes Japan's weak diplomatic stance versus China on the one hand, but refutes the declinist narrative on the other. See also H. Tanaka, 'China's spat with Japan: Out but not over', The Economist (24 September 2010). Other perceptions by analysts and media are more moderate, calling Japan the more rational, reasonable party, while depicting China as the irrational, aggressive, non-trustworthy player.

32. 'Dominant narrative' is used here as being the dominant ideology of a society, thus what most of the society believes to be true.

33. G. L. Curtis (10 December 2012) 'Japan's decline: An unhelpful diversion', East Asia Forum. http://www.eastasiaforum.org/2012/12/10/japansdecline-an-unhelpful-diversion/ (accessed 28 July 2013); G. L. Curtis (1 December 2012) 'The pointless debate over Japan's decline', The Diplomat. http://thediplomat.com/2012/12/01/the-pointless-debate-over-japansdecline/ (accessed 28 July 2013); E. Fingleton (6 January 2012) 'The myth of Japan's failure', New York Times. http://www.nytimes.com/2012/01/08/ opinion/sunday/the-true-story-of-japans-economic-success.html?page wanted=all (accessed 28 July 2013); E. Fingleton (26 February 2011) 'The myth of Japan's lost decades', The Atlantic. http://www.theatlantic.com/inter national/archive/2011/02/the-myth-of-japans-lost-decades/71741/ (accessed 28 July 2013); P. Krugman (5 February 2013) 'The Japan Story', The New York Times. http://krugman.blogs.nytimes.com/2013/02/05/the-japanstory/?_r=0 (accessed 28 July 2013).

34. T. Hitoshi (2012) 'Myths of decline: Why Japan matters as China rises', East Asia Insights, 7/5, pp.1-3.

35. Dittmer and Kim, 'In search of a theory of national identity', pp.16-17.

36. D. Rustow (1967) A World of Nations: Problems of Political Modernization (Washington: Brookings Institution), p.22.

37. There are differing opinions about who collided with whom and whether it was a deliberate act. Examples of very detailed analyses and video footage can be found online. E.g. http://sun-bin.blogspot.be/2010/11/which-shiphas-made-change-in-direction.html (accessed 28 July 2013). 
38. MOFA (25 September 2010) 'Statement by the Press Secretary/DirectorGeneral for Press and Public Relations, Ministry of Foreign Affairs, on the Collision between Japan Coast Guard Patrol Vessels and a Chinese Fishing Trawler in Japan's Territorial Waters off the Senkaku Islands'. http://www. mofa.go.jp/announce/announce/2010/9/0925_01.html (accessed 28 July 2013).

39. 'Japan frees Chinese boat captain amid diplomatic row', BBC News World, 24 September 2010. http://www.bbc.co.uk/news/world-11403241 (accessed 28 July 2013). 'Chūgokujin senchō wo shakuhō he: Naha chiken 'Nichū kankei wo $k \bar{o} r y \bar{o}^{\prime}$ (Towards the release of the Chinese captain, the Naha district officer says: 'We should reconsider Sino-Japanese relations'), Nihon Keizai Shimbun, 24 September 2010. http://web.archive.org/web/20100926015209/http:// www.nikkei.com/news/headline/article/g=96958A9C93819695E0E6E2E0978 DE0E6E2EBE0E2E3E2E2E2E2E2E2E2 (accessed 28 July 2013).

40. L. Hagström (2012) " "Power shift" in East Asia? A critical reappraisal of narratives on the Diaoyu/Senkaku Islands incident in 2010', The Chinese Journal of International Politics 5, 267-97; Y. Tiberghien (2010) 'The puzzling 2010 Diaoyu crisis: Centrifugal domestic politics, shifting balance of power, and weak regional institutionalization', Harvard Asia Quarterly, 74.

41. 'Kan seeks intl stage for Senkaku spat solution', The Yomiuri Shimbun, 29 September 2010. http://web.archive.org/web/20101007212409/ http:// www.yomiuri.co.jp/dy/national/T100928004733.htm (accessed 28 July 2013). 'China's spat with Japan: Out but not over', The Economist, 24 September 2010. 'China signals V for Victory', Asia Times Online, 5 October 2010. http://www.atimes.com/atimes/Japan/LJ05Dh01.html (accessed 28 July 2013).

42. 'China cuts 2010 rare earth export quota 40 pct-paper', Reuters, 11 August 2010. http://www.reuters.com/article/2010/08/11/china-minormetals-idAFT OE67A03H20100811 (accessed 28 July 2013). 'China, Japan debate restrictions on rare earth exports', People's Daily Online, 30 August 2010. http://english.peopledaily.com.cn/90001/90778/90861/7122382.html (accessed 28 July 2013). As mentioned by Hagström, "Power shift" in East Asia?', 282.

43. 'Interview with L. Hagström', Japan Foreign Policy Observatory, 21 June 2012. http://www.japanfpo.org/2012/06/interview-with-linus-hagstrom.html (accessed 28 July 2013).

44. L. Hagström, 'China-Japan tensions over Senkaku purchase an orchestrated affair', East Asia Forum, 17 September 2012. http://www.eastasiaforum.org/ 2012/09/17/china-japan-tensions-over-senkaku-purchase-an-orchestratedaffair/ (accessed 28 July 2013).

45. 'Spin and Substance: Should the United States be impressed by Shinzo Abe or worried by him?', The Economist, 2 March 2013. http://www.economist. com/news/asia/21572795-should-united-states-be-impressed-shinzo-abeorworried-him-spin-and-substance (accessed 28 July 2013).

46. We can even consider the 2010 trawler collision near the Senkaku Islands an influencing event, as it had a strong impact on public opinion and as such might have supported the security policy favored by the then ruling DPJ, which is reflected in the adjusted National Defense Program Guidelines of 2011. Ministry of Defense, Government of Japan, 'National 
Defense Program Guidelines for 2011 and beyond' (10 December 2010). http://www.mod.go.jp/e/d_act/d_policy/pdf/guidelinesFY2011.pdf (accessed 28 July 2013).

47. This is interesting considering the fact that during his first term as prime minister (2006-2007) Abe, despite being known as an anti-Chinese nationalist, tried to ameliorate relations with China. China's Government Official Web Portal, 'Japan's Abe visits China: "turning point" in relations' (9 October 2006). http://www.gov.cn/misc/2006-10/09/content_407481.htm (accessed 28 July 2013).

48. Ministry of Defense, Government of Japan, 'Defense of Japan 2013'. http:// www.mod.go.jp/e/publ/w_paper/2013.html (accessed 28 July 2013). In a similar way, the DPRK is presented as a threat in order facilitate changes to Japanese foreign security policy.

49. 'Japan runs risk of playing with fire', People's Daily Online, 10 July 2013. http://english.peopledaily.com.cn/90883/8318985.html (accessed 28 July 2013). 'Defense paper shows Tokyo's hysteria', Global Times, 10 July 2013.

50. Moon and Suh, 'Identity politics, nationalism, and the future of the Northeast Asian order', p.213.

51. T. Akaha (2008) 'The nationalist discourse in contemporary Japan: The role of China and Korea in the last decade', Pacific Focus, 23/2, 156.

52. The Prime Minister of Japan and his Cabinet, 'The Bounty of the Open Seas: Five New Principles of Japanese Diplomacy' (18 January 2013). http://www. kantei.go.jp/foreign/96_abe/statement/201301/18speech_e.html (accessed 28 July 2013).

53. The Prime Minister of Japan and his Cabinet, 'Japan is Back', Policy Speech by Prime Minister Shinzô Abe at the Center for Strategic and International Studies (CSIS) (22 February 2013). http://www.kantei.go.jp/foreign/96_abe/ statement/201302/22speech_e.html (accessed 28 July 2013).

54. US Department of State, Hillary Rodham Clinton, 'Remarks with Japanese Foreign Minister Fumio Kishida after their meeting' (18 January 2013). http://www.state.gov/secretary/rm/2013/01/203050.htm (accessed 28 July 2013).

55. Kazuyuki Katayama, 'Cinq vérités sur les îles Senkaku', l’Echo, 8 November 2012. http://www.be.emb-japan.go.jp/document/5_truths_on_Senkaku.pdf (accessed 28 July 2013).

56. 'Chinese media accuse Abe of dangerous politics', Japan Today, 18 July 2013. http://www.japantoday.com/category/politics/view/chinese-media-accuseabe-of-dangerous-politics (accessed 28 July 2013).

57. The Prime Minister of Japan and his Cabinet, 'The Bounty of the Open Seas: Five New Principles of Japanese Diplomacy' (18 January 2013).

58. Ted Galen Carpenter, 'Japan's Containment Strategy', China-US Focus, 17 June 2013. http://www.chinausfocus.com/foreign-policy/japans-contain ment-strategy-against-china/ (accessed 28 July 2013). 'Evolution of Japan's grand strategy', East Asia Forum, 4 June 2013. http://www.eastasiaforum.org/ 2013/06/04/evolution-of-japans-grand-strategy/ (accessed 28 July 2013).

59. They believe that Japan's post-war pacifism, most visible in Article 9 of its Constitution that renounces war, allows other countries such as the US, but also China, to set the limits of Japan's international power and 


\section{PROOF}

Tine Walravens 141

influence. See Akaha, 'The nationalist discourse in contemporary Japan', $156-88$.

60. Dittmer and Kim, 'In search of a theory of national identity', p.2.

61. For an accurate description of what can be understood as China's core interests, see Jerdén and Hagström, 'Rethinking Japan's China policy', 215-50.

62. L. W. Pye (1971) 'Identity and the political culture', in Binder and J. La Palombara (eds.) Crises and Sequences in Political Development (Princeton: Princeton University Press), p.111. 


\section{PROOF}

\section{QUERIES TO BE ANSWERED BY AUTHOR (SEE MARGINAL MARKS)}

IMPORTANT NOTE: Please mark your corrections and answer to these queries directly onto the proof at the relevant place. Do NOT mark your corrections on this query sheet.

\section{Chapter 7}

\begin{tabular}{lll}
\hline Query No. & Page No. & \multicolumn{2}{c}{ Query } \\
\hline AQ1 & 125 & $\begin{array}{l}\text { Please check the placement of the } \\
\text { figure is ok? } \\
\text { AQ2 }\end{array}$ \\
\hline
\end{tabular}

